九州大学学術情報リポジトリ

Kyushu University Institutional Repository

Comparative Analysis of Paralytic Shellfish

Toxin Content and Profile Produced by

Dinoflagellate Gymnodinium Catenatum Isolated from Inokushi Bay, Japan

Oh, Seok Jin

Korea Inter-University Institute of Ocean Science, Pukyong National University

Matsuyama, Yukihiko

National Research Institute of Fisheries and Environment of Inland Sea, Fisheries Research Agency

Yoon, Yang Ho

College of Fisheries and Ocean Science, Chonnam National University

Mi yamura, Kazuyoshi

Fisheries Research Institute 0ita Prefectural Agriculture, Forestry and Fisheries Research Center

他

https://doi.org/10.5109/17799

出版情報: 九州大学大学院農学研究院紀要. 55 (1)，pp.47-54，2010-02-26. Faculty of Agriculture， Kyushu University

バージョン :

権利関係: 


\title{
Comparative Analysis of Paralytic Shellfish Toxin Content and Profile Produced by Dinoflagellate Gymnodinium Catenatum Isolated from Inokushi Bay, Japan
}

\author{
Seok Jin OH ${ }^{1}$, Yukihiko MATSUYAMA ${ }^{2}$, Yang Ho YOON ${ }^{3}$, Kazuyoshi MIYAMURA ${ }^{4}$, \\ Chang Geun CHOI ${ }^{1}$, Han-Soeb YANG ${ }^{1}$ and Ik Joon KANG*
}

\author{
Aquatic Biomonitoring and Environmental Laboratory, Department of Bioscience and \\ Biotechnology, Faculty of Agriculture, Kyushu University, \\ Fukuoka 812-8581, Japan \\ (Received Nobember 2, 2009 and accepted November 19, 2009)
}

\begin{abstract}
Paralytic shellfish toxin contents and profiles were investigated using shellfish toxin-producing dinoflagellate Gymnodinium catenatum strains isolated from Inokushi Bay during the March and July 2002 outbreak. The March strains, which were 72 strains isolated from bloom water, exhibited average growth rates of 0.25 divisions day ${ }^{-1}$ due to sub-optimal temperature. The average toxin content was $321 \mathrm{f} \mathrm{mole} \mathrm{cell}{ }^{-}$ The principal toxin were $\mathrm{C} 1+2(79.8 \mathrm{~mole} \%)$ and GTX 5+6 (18.0 mole\%), and minor components were characterized as GTX 2+3, dcGTX2+3, and neoSTX+STX. Interestingly, 7 strains were clearly distinguished from those of other strains by the complete presence of GTX1+4. In the July strains, which were 33 strains isolated from bloom water, the average growth rate and toxin content was 0.34 divisions day $^{-1}$ and $160 \mathrm{f}$ mole cell ${ }^{-1}$, respectively. C1+2 (83.3 mole\%) and GTX 5+6 (10.6 mole\%) were the principal toxins, as in the March strains. However, carbamoyl toxins in the July strains were increasing with decreasing $\mathrm{N}$-sulfocarbamoyl toxins in the Mach strains. We also observed major changes in toxin profile, evident by the increase of $\mathrm{C} 1+2$ and the decrease of GTX $5+6$ in response to increasing temperature, using a single March strain. Minor components of July strains were characterized by GTX2+3, neoSTX, STX and dcGTX2+3. Thus, if we were to consider the toxin profile percentage based on temperature variation, $G$. catenatum outbreaks in March and July may have originated from one and the same population.
\end{abstract}

Keywords: Gymnodinium catenatum; paralytic shellfish toxin; toxin content; toxin profile; Inokushi Bay

\section{INTRODUCTION}

Gymnodinium catenatum Graham is a toxic dinoflagellate that causes paralytic shellfish poisoning (PSP) in coastal waters (Hallegraeff et al., 1989). The first $G$. catenatum bloom associated with PSP was reported from Spain in 1977 (Estrada et al., 1984), followed by cases of human fatalities from the Gulf of California in 1979 (Morey-Gaines, 1982). Reports that this species had spread across many parts of the world began to appear (Hallegraeff et al., 1989). In Japan, G. catenatum was first suspected to be involved with PSP outbreaks in Senzaki Bay of western Japan, 1986. Since then, contaminations have occurred almost every year in western Japan (Ikeda et al., 1989; Nishioka et al., 1993; Baba et al., 2001). The introduction (e.g. through ballast water) or migration of $G$. catenatum to central and northern Japan is possible where the maximum surface water temperature of $20^{\circ} \mathrm{C}$ is favorable for this species

Korea Inter-University Institute of Ocean Science,Pukyong National University, 599-1 Daeyeon-dong, Nam-gu, Busan 608-737 Korea

National Research Institute of Fisheries and Environment of Inland Sea, Fisheries Research Agency 2-17-5 Maruishi, Hatsukaichi, Hiroshima 739-0452, Japan

${ }^{3}$ College of Fisheries and Ocean Science, Chonnam National University San 96-1, Dundeok-dong, Yeosu 550-749, Korea

${ }^{4}$ Fisheries Research Institute Oita Prefectural Agriculture, Forestry and Fisheries Research Center, Kamiura, Saiki, Oita, 879-2602, Japan

* Corresponding author (E-mail: kangnew@agr.kyushu-u.ac.jp)
(Matsuoka and Fukuyo, 1994).

It has been proven that the capability to produce certain toxin profile is inherited (Anderson, 1990; Oshima et al., 1993a, b). Given that differences in toxin profiles have a genetic basis, specific toxin profile might be used as biochemical markers for a number of PSP-producing dinoflagellate species. However, toxin profiles can vary due to differing environmental conditions (Ogata et al., 1987; Maranda et al., 1985; Cembella et al., 1987; Boyer et al., 1987; Boczar et al., 1988; Anderson, 1990; Ishida et al., 1993; Taroncher-Oldenburg et al., 1997). Given this fact, a number of studies investigated species population dynamics based on toxin profiles. For example, Chang et al. (1997) reported on the toxin profile of Alexandrium minutum isolated from coastal areas of New Zealand, showing that is was quite different from that of species isolated from other parts of the world. It is quite possible that $A$. minutum may have been introduced to New Zealand via ballast water given its isolated location and high maritime traffic from all around the world. In Australia, G. catenatum is regarded as an exotic species since only being noticed in coastal waters from the 1980's, and supported by the fact that its cysts were not observed in sediment prior to 1980s. Hallegraeff and Bolch (1992) suggested that cysts of G. catenatum were brought to Tasmania by ballast water in ships from Japan and Korea. However, toxic profiles of the Tasmanian strains are clearly distinguishable from those isolated from Japan (Oshima et al., 1993a). This might indicate whether they are autochthonal species or intro- 
duced from countries other than Japan and Korea. Recently, Park et al. (2004) observed strains produced C3 and C4 toxins around Korean coastal waters, similar to the Tasmanian strains.

A major causative organism of PSP in Inokushi Bay, which has the highest production of cultured shortnecked clam in Japan, was reported to be $G$. catenatum (Miyamura et al., 2007). This species has been observed in the bay throughout the year, which is of interest as water temperatures between winter and summer are significantly different. Moreover, G. catenatum attributed PSP events in summer did not occur in conjunction with G. catenatum outbreak in the bay, in spite of increasing cell density. This may have been due to specific physiological conditions related to environmental parameters between summer and winter. The aim of this study was to compare the population dynamics of $G$. catenatum between the May and July 2002 blooms, based on toxin profiles in the bay.

\section{MATERIALS AND METHODS}

\section{Culture isolates of Gymnodinium catenatum}

G. catenatum was isolated from Inokushi Bay, Oita Prefecture, Japan (Fig. 1) in March and July 2002 on a light microscope using a micropipette (ca. ø 50-100 $\mu \mathrm{m}$ ), coinciding with high cell numbers in the water column (Fig. 2). Temperature and salinity were observed using a conductivity-temperature-depth system (Model 58, YSI/ Nanotech Inc., Tokyo, Japan). The isolated cells were rinsed at least four times by filtered seawater $(0.22 \mu \mathrm{m}$ pore size; GSWP, Millipore, MA, USA), and then placed in culture tubes with $5 \mathrm{ml}$ modified $\mathrm{f} / 2$ medium (Guillard and Ryther, 1962) sterilized at $121^{\circ} \mathrm{C}$ for $1 \mathrm{hr}$. From sea-

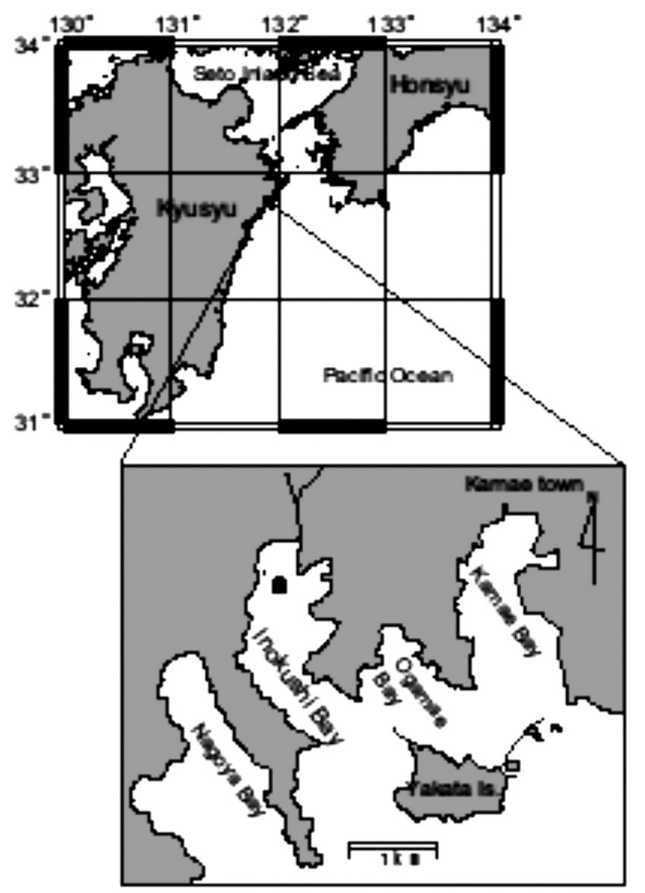

Fig. 1. Study area in Inokushi Bay, Japan sampling station)
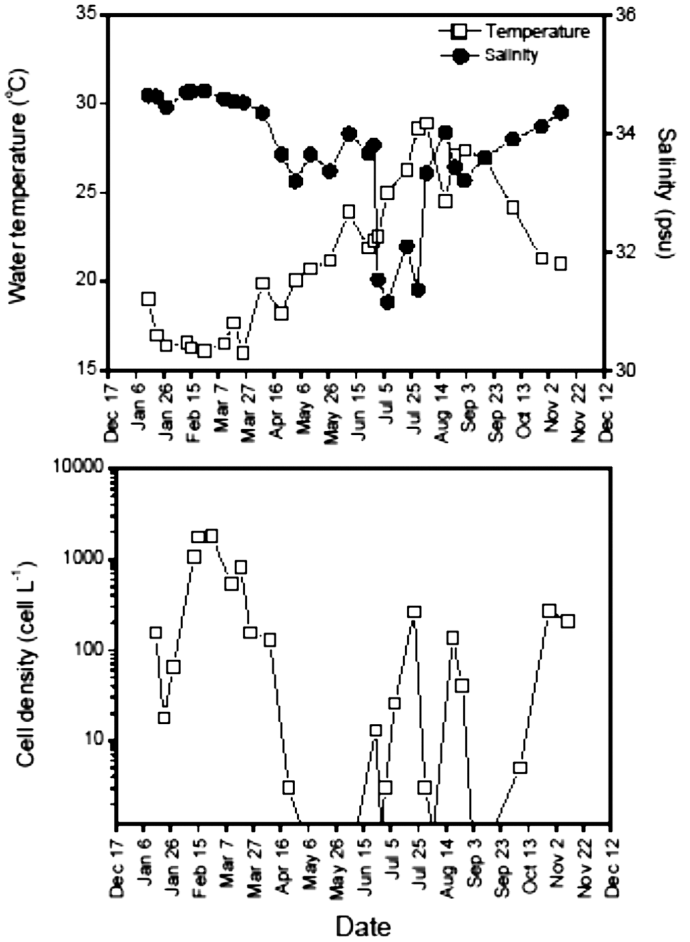

Fig. 2. Temporal changes of temperature, salinity and cell density of Gymnodinium catenatum in Inokushi Bay, 2002.

water sampled in March and July, 72 and 33 clonal strains of $G$. catenatum were isolated, respectively (hereafter referred to as the March and July strains). Isolated cells were cultured at $30 \mathrm{psu}$, with an illumination of $100 \mu \mathrm{mol}$ $\mathrm{m}^{-2} \mathrm{~s}^{-1}$ using cool-white fluorescent lamps (12 h light: $12 \mathrm{~h}$ dark cycle). Incubation temperature was set at the in situ temperature $\left(18^{\circ} \mathrm{C}\right.$ for March strains and $25^{\circ} \mathrm{C}$ for July strains). Culturable cells (i.e. viable strains after isolation) were 55 of the 73 March strains (76.4\%) and 28 of the 33 July strains (84.8\%). To remove substances such as ammonia and metals, all equipment and glassware were washed with approximately 30\% v/v HCl and thoroughly rinsed with distilled water before being autoclaved (202 kPa, $20 \mathrm{~min}$ ).

Growth rate (division day ${ }^{-1}$ ) estimates of each strain were calculated using a least square regression on logtransformed cell density data during exponential growth phase:

$$
\mu=\frac{1}{\Delta t} \ln \frac{N_{t}}{N_{0}},
$$

where

$\mathrm{N}_{0}, \mathrm{~N}_{\mathrm{t}}$ : initial and final in vivo fluorescence of the exponential period (cells $\mathrm{ml}^{-1}$ ),

$\Delta$ t: period of exponential growth phase (day).

\section{Cell harvest and toxin analysis}

Cultured cells were harvested by a plankton net $(10 \mu \mathrm{m}$ pore size) in late exponential phase at 6:00 p.m. Pellets were extracted with $0.03 \mathrm{~N}$ acetic acid by sonication, and cell debris removed by centrifugation $(10,000 \mathrm{~g}$ $\times 10$ min). Analysis of PSP toxins using high-performance 
liquid chromatography with fluorescence detection (Model-700, Hitachi, Tokyo, Japan) was performed following the post-column oxidative fluorescence method of Oshima (1995). Toxins were resolved by reversephase chromatography using a silica-base column (Inertsil C8; $0.46 \times 15$ cm, GL Science, Tokyo, Japan). Three separate isocratic elutions were employed to separate the spectrum of PSP-toxins at a flow of $0.8 \mathrm{ml} \mathrm{mim}^{-1}$. The gonyautoxins (GTX1-4) and the N-sulfocarbamoyl toxin were resolved using $10 \mathrm{mM}$ aqueous ammonium phosphate at $\mathrm{pH} 7.1$, with $2 \mathrm{mM}$ heptane sulfonate (Na salt) serving as the ion-pairing reagent. To separate neosaxitoxin (neoSTX) and saxitoxin (STX), $2 \mathrm{mM}$ heptane sulfonate ( $\mathrm{Na}$ salt) was substituted as the ion-pairing reagent in $30 \mathrm{mM}$ aqueous ammonium phosphate buffer $(\mathrm{pH}$ 7.1) with $4 \%$ acetonitrile. The N-sulfocarbamoyl (C-) toxins were resolved using $2 \mathrm{mM}$ tetrabutyl ammonium phosphate adjusted to $\mathrm{pH} 6$ as the mobile phase. The eluate from the column was continuously mixed with $7 \mathrm{mM}$ periodic acid in $50 \mathrm{mM}$ sodium phosphate buffer (pH 9.0) at $0.4 \mathrm{ml} \mathrm{mim}^{-1}$, heated at $65^{\circ} \mathrm{C}$ by passing through Teflon tubing and then mixed with $0.5 \mathrm{~N}$ acetic acid at $0.4 \mathrm{ml} \mathrm{mim}^{-1}$ just before entering the monitor. The fluoromonitor was set at an excitation wavelength of $330 \mathrm{~nm}$ and emission of $390 \mathrm{~nm}$.

Gonyautoxins 5 and 6 (GTX 5+6) were determined in accordance with the increased yield of neosaxitoxin (neoSTX) and saxitoxin (STX) formed after heating (1 hr, $100{ }^{\circ} \mathrm{C}$ ) with addition of $0.1 \mathrm{~N} \mathrm{HCl}$ (Nagashima et al., 1987), as the standard toxins for GTX $5+6$ were not available. Meanwhile, STX, neoSTX, gonyautoxins 1-4 (GTX1-4), decarbamoylgonyautoxins 2+3 (dcGTX2+3) and $\mathrm{C} 1-4$ were estimated from standard toxins obtained from Japan Fisheries Resource Conservation Association, and/or from Prof. Yasukatsu Oshima of Tohoku University, Japan. The results were expressed in relative amounts of each toxin on a molar basis (mol\%) and toxic content (f mole cell ${ }^{-1}$ ).

Toxin contents and profiles of Gymnodinium catenatum in response to changing temperature

To examine the toxin contents and profiles of $G$. catenatum in response to changing temperatures, we used a single strain (GCINO2002M14) isolated from Inokushi Bay in March 2002. The effect of temperature was determined at $18{ }^{\circ} \mathrm{C}$ and $25^{\circ} \mathrm{C}$, which corresponded to the in situ temperature of each sampling period. Salinity and irradiance was constant during incubation period (30 psu and $100 \mu \mathrm{mol} \mathrm{m} \mathrm{m}^{-2} \mathrm{~s}^{-1}$ ). To avoid culture shock due to change in incubated temperature, temperatures of cultures were raised about $1{ }^{\circ} \mathrm{C}$ a day, and were finally maintained at $25{ }^{\circ} \mathrm{C}$. The acclimated cells were inoculated into five replicate flasks with fresh modified $\mathrm{f} / 2$ medium at $18^{\circ} \mathrm{C}$ and $25^{\circ} \mathrm{C}$. Toxin content was estimated using cells in late exponential phase as mentioned above.

\section{RESULTS}

Relationship between hydrographic condition and cell density of Gymnodinium catenatum

Temperature and salinity during the sampling period ranged from $16.0-28.9^{\circ} \mathrm{C}$ and $31.15-34.72 \mathrm{psu}$, respectively (Fig. 2). G. catenatum exhibited increasing cell density from January to March $\left(16-21^{\circ} \mathrm{C}\right.$ and 34.0 $35.0 \mathrm{psu})$, and from July to August $\left(25-27^{\circ} \mathrm{C}\right.$ and 31-32 psu). Maximum cell density was obtained at

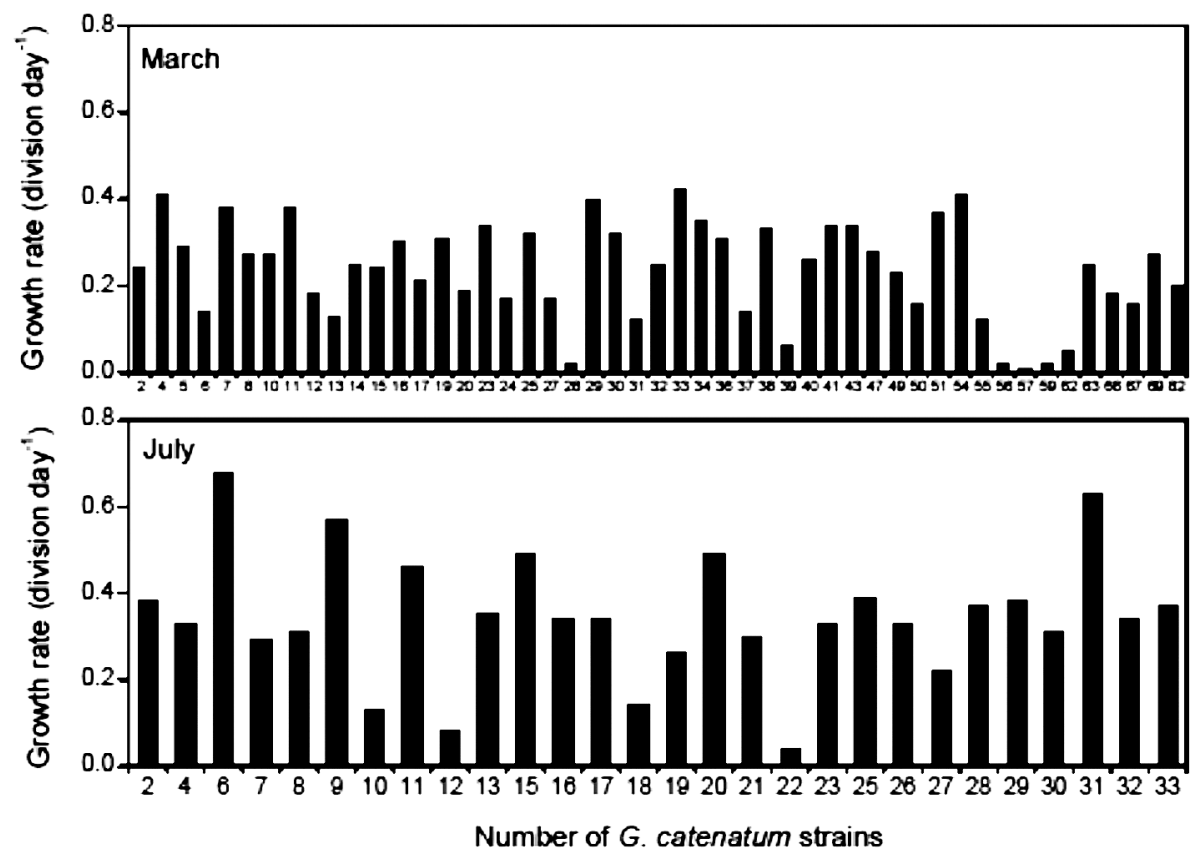

Fig. 3. Growth rates of Gymnodinium catenatum isolated from Inokushi Bay in March and July, 2002. Experimental conditions; $18^{\circ} \mathrm{C}$ for strains isolated from the March strain and $22^{\circ} \mathrm{C}$ for the July strains. Salinity 30, pH 8.0, $300 \mathrm{umol} \mathrm{m}^{-2} \mathrm{~s}^{-1}$ (cool-white fluorescent lamps, 12:12 h LD cycle). 


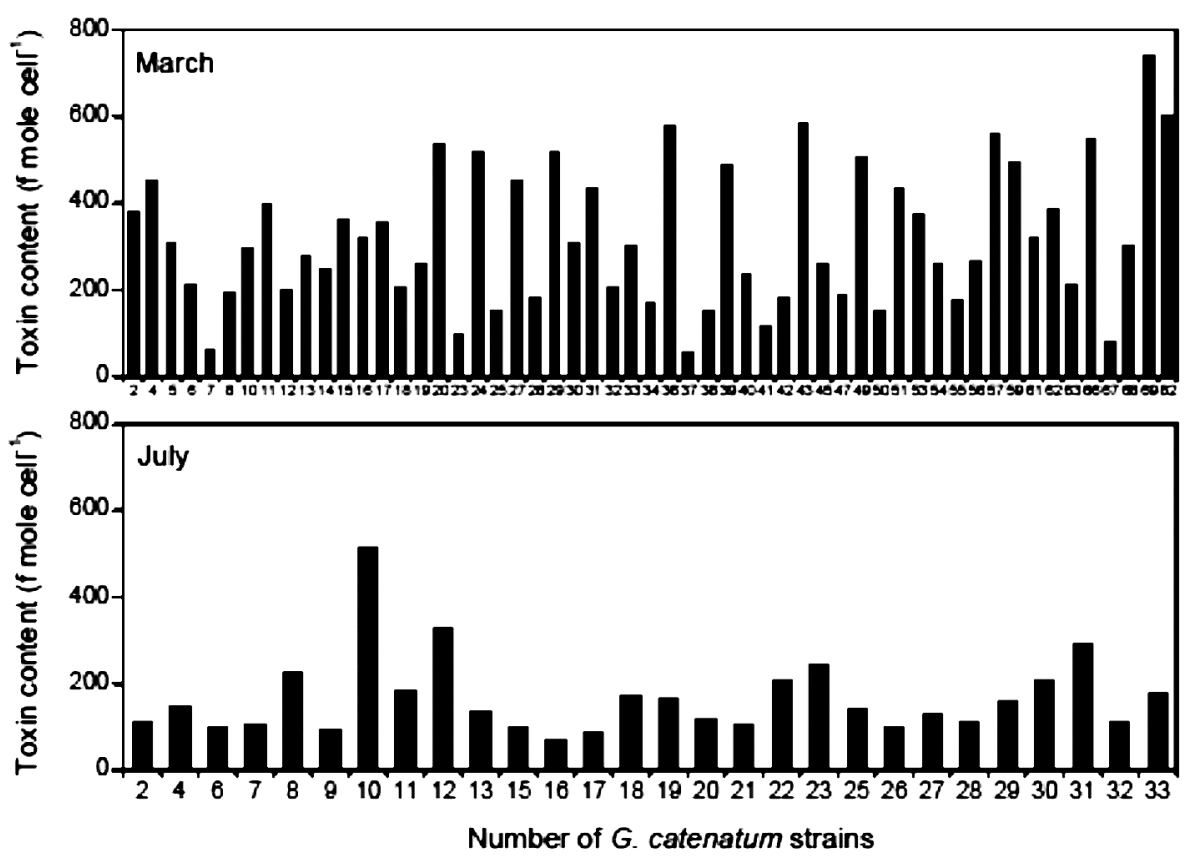

Fig. 4. Toxin contents of Gymnodinium catenatum isolated from Inokushi Bay in March and July, 2002. Cultured cells were harvested by plankton net ( $20 \mu \mathrm{m}$ pore size) in late exponential phase (See Fig. 3 for incubation conditions).

$16.1^{\circ} \mathrm{C}$ and $34.72 \mathrm{psu}\left(1,808\right.$ cells $\left.\mathrm{L}^{-1}\right)$. However, cell densities from July to August remained at 265 cells $\mathrm{L}^{-1}$, which was lower than that of February (temperature $26.3{ }^{\circ} \mathrm{C}$ and salinity $32.09 \mathrm{psu}$ ).

Toxin contents and profiles of Gymnodinium catenatum strains isolated from Inokushi Bay

Growth rates of individual strains are shown in Fig. 3. The average growth rates were significantly different at 0.25 division day $^{-1}$ for the March strains and 0.34 division day $^{-1}$ for the July strains (one-way ANOVA; $\mathrm{P}<0.001$ ). The average toxin content was $321 \pm 160 \mathrm{f}$ mole cell -1 in

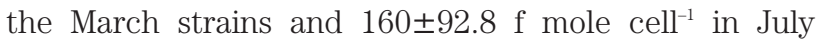
strains. Non-toxin strains were not observed. Toxin

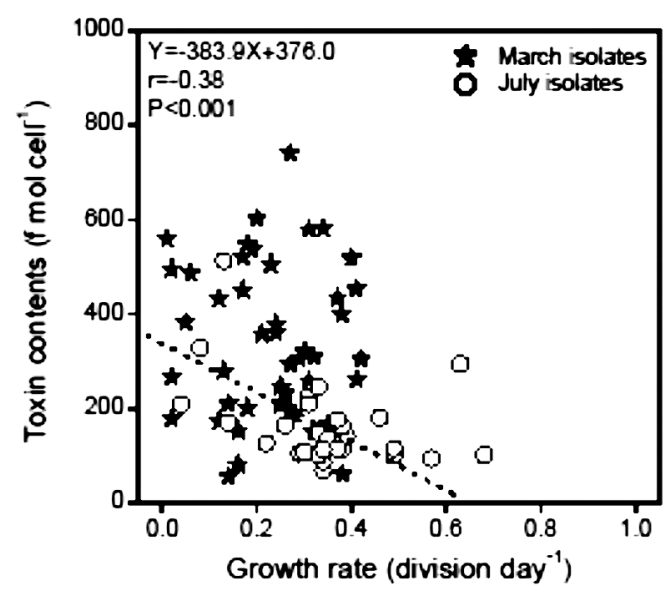

Fig. 5. Correlation between growth rate and toxin contents of Gymnodinium catenatum isolated from Inokushi Bay in March and July, 2002. content of the strains varied greatly between the minimum (56.6 $\mathrm{f}$ mole cell ${ }^{-1}$ ) and maximum values $(740 \mathrm{f}$ mole cell ${ }^{-1}$; Fig. 4). Moreover, a one-way ANOVA indicated that variability of toxin contents were significant among individual strains $(p<0.001)$. When toxin contents were plotted against individual growth rates, the relationship showed an inverse linear trend, despite the low correlation coefficient $(\mathrm{r}=-0.38 ; \mathrm{P}<0.001$; Fig. 5).

In the toxin profile of the March strains, $\mathrm{C} 1+2$ toxin was the dominant toxin (ca. 79.8 \pm 10.0 mole\% among whole PSP toxin; Fig. 6). However, C3+4 toxin was completely absent in all strains. GTX5+6 toxin was occupied by proportions of $18.0 \pm 8.42$ mole\%. Minor components of the March strains were characterized by GTX2+3 $(0.21 \pm 0.37$ mole $\%)$, dcGTX2+3 (0.32 \pm 0.25 mole\%) and neoSTX+STX (1.65 \pm 3.11 mole\%) (Fig. 6). In the July strains, proportions of $\mathrm{C} 1+2$ and GTX $5+6$ toxins were $83.3 \pm 6.63$ mole $\%$ and $10.6 \pm 5.78$ mole\%, respectively. In contrast, minor components were characterized by GTX2+3 (2.26 \pm 2.78 mole\%), dcGTX2+3 (0.72 \pm 0.79 mole\%) and neoSTX+STX (3.14 23.37 mole\%; Fig. 7).

Toxin content and profiles of Gymnodinium catenatum under different water temperatures

Table 1 shows the toxin content of $G$. catenatum strain (GCINO2002M14) incubated at $18{ }^{\circ} \mathrm{C}$ and $22^{\circ} \mathrm{C}$ with in situ temperature. The toxin content of strain incubated at $18{ }^{\circ} \mathrm{C}$ and $25^{\circ} \mathrm{C}$ were $136 \pm 21.6 \mathrm{f}$ mole cell $^{-1}$ and $58.0 \pm 20.3 \mathrm{f} \mathrm{mole} \mathrm{cell}^{-1}$, respectively. The toxin contents in $18^{\circ} \mathrm{C}$ were ca. 2 times higher than those of $25^{\circ} \mathrm{C}$. This corresponded well with results which showed that average toxin contents of the March strains were 2 times higher. The toxin profile also varied with that of $\mathrm{C} 1+2$ 

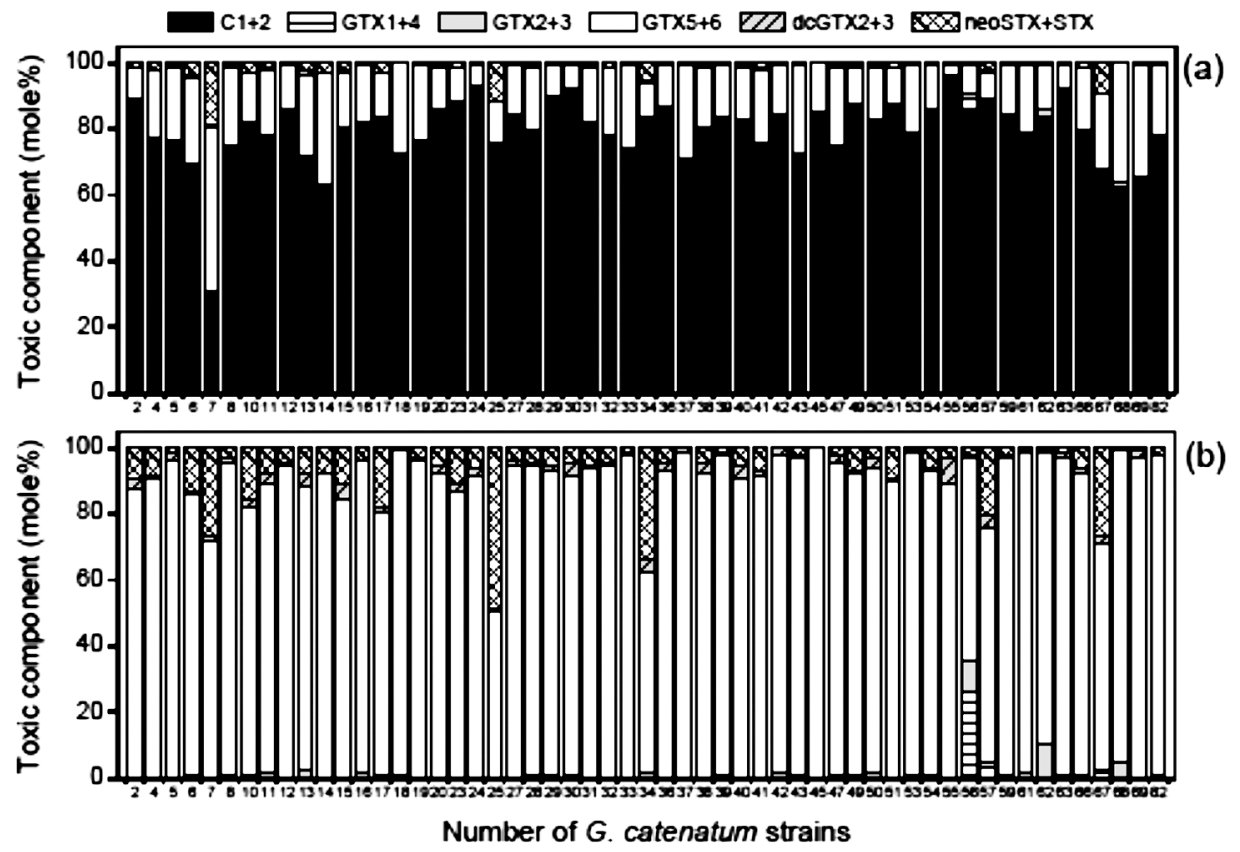

Fig. 6. (a) Toxin profiles in Gymnodinium catenatum isolated from Inokushi Bay in March, 2002. (b) Toxin profiles of G. catenatum strains, with the exception of $\mathrm{C} 1+2$ (See Fig. 3 for incubation conditions).
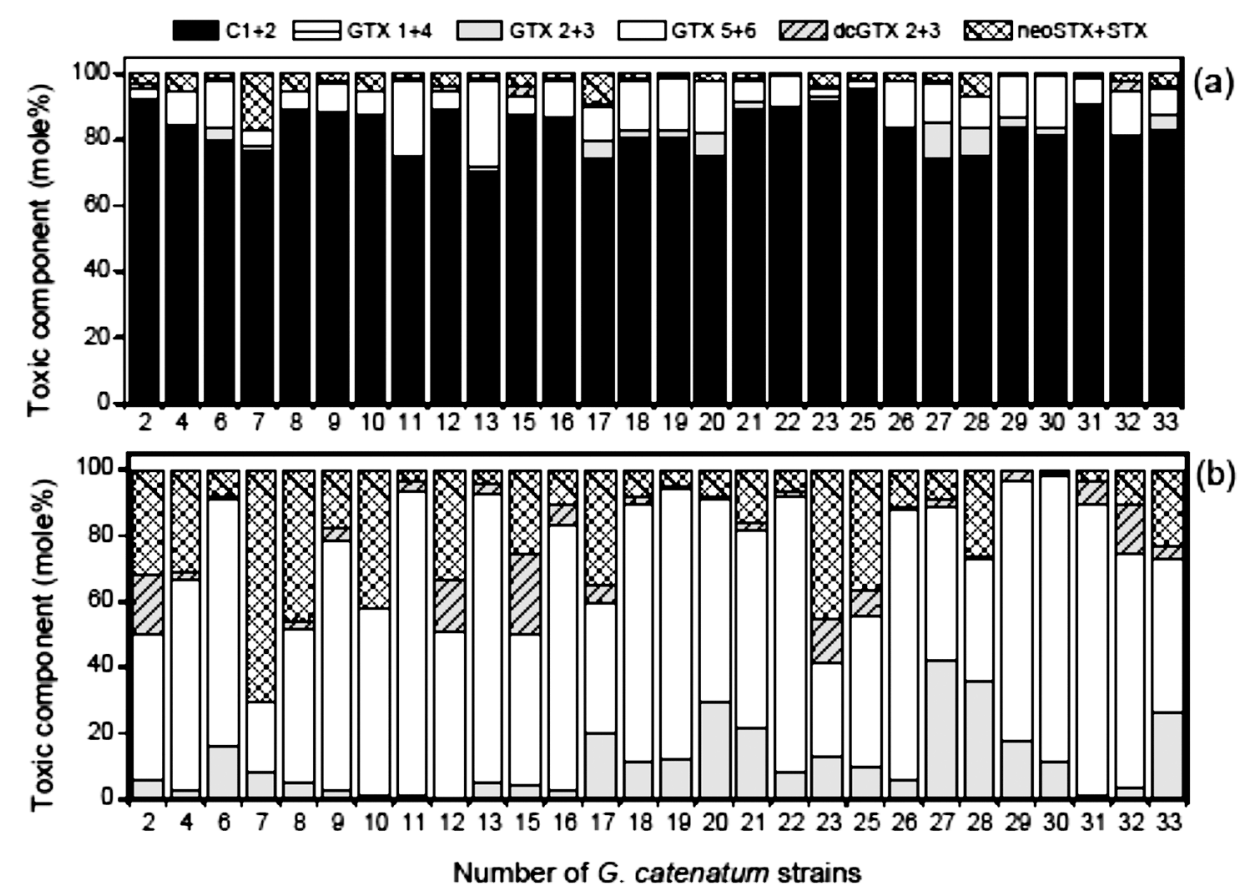

Fig. 7. Toxin profiles in Gymnodinium catenatum isolated from Inokushi Bay in July, 2002. (b) Toxin profiles of G. catenatum strains, with the exception of C1+2 (See Fig. 3 for incubation conditions).

increasing from $50.6 \pm 1.30$ mole $\%$ to $76.9 \pm 1.68$ mole $\%$, while GTX $5+6$ decreased from $48.5 \pm 1.31$ mole $\%$ to $22.0 \pm 1.71$ mole\% with increasing temperature, although GTX2+3 did not vary between the two temperature ranges (neoSTX+STX was not detected; Fig. 8).

\section{DISCUSSION}

G. catenatum blooms occur from January to March and from July to August in Inkoushi Bay. Water temperature during these outbreaks ranged from $16{ }^{\circ} \mathrm{C}$ to $21{ }^{\circ} \mathrm{C}$ 


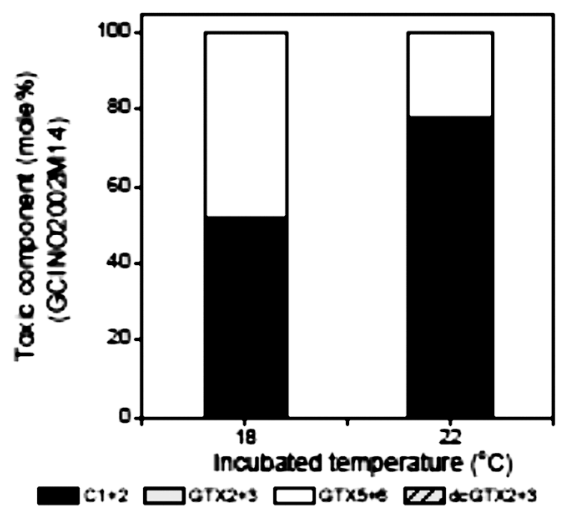

Fig. 8. Changes in toxin profile of Gymnodinium catenatum with increasing temperature from $18{ }^{\circ} \mathrm{C}$ to $25^{\circ} \mathrm{C}$.

and from $25^{\circ} \mathrm{C}$ to $27^{\circ} \mathrm{C}$, respectively. Bravo and Anderson (1994) reported that the optimum temperature of the Spanish strain was between $22-28^{\circ} \mathrm{C}$. In tropical regions, such as Palau, Venezuela and Philippines, optimum growth temperature is between $23-29^{\circ} \mathrm{C}$ (Hallegraeff and Fraga, 1998). In laboratory experiments using strains isolated from Hiroshima Bay of Japan and Yosuhea Bay of Korea, optimum temperatures ranged from $20-30{ }^{\circ} \mathrm{C}$ (Yamamoto et al., 2002; Oh and Yoon, 2004). These temperatures are consistent with temperatures observed in this study from July to August. However, the Tasmanian strain was able to better grow in lower temperatures (Hallegraeff et al., 1989). Blooms in Tasmanian waters occur from December to June when water temperature ranges from $12{ }^{\circ} \mathrm{C}$ to $18{ }^{\circ} \mathrm{C}$, which were replicated in laboratory experiments by Blackburn et al. (1989). These temperatures are consistent with temperature from January to March of this study.

G. catenatum outbreaks in Inokushi Bay during different temperature ranges indicate the presence of various populations with different physiological characteristics. Sakamoto and Kotani (1998) reported that Alexandrium tamarense isolated from Hiroshima Bay have plural populations due to wide variation of toxin profiles among strains isolated from the same seawater. Ichimi et al., (2002) also suggested the presence of various planktonic populations around the same area. Based on these informations, we cannot rule out the possibility that the same population is in fact present during both sampling periods, compared to the notion that two different populations were present.

Average of growth rate was 0.25 division day $^{-1}$ in the March strains and 0.34 division day ${ }^{-1}$ in the July strains (Fig. 3). Different studies have reported maximum growth rates of $G$. catenatum at 0.4 divisions day ${ }^{-1}$ from the Denmark strain (Ellegaard et al., 1993), 0.53 divisions day ${ }^{-1}$ from the Spanish strain (Bravo and Anderson 1994) and 0.44 divisions day ${ }^{-1}\left(0.31\right.$ day $^{-1}$ in the original paper) from the Japan and Korea strains (Yamamoto et al., 2002; Oh et al., 2004) These maximum growth rates were similar to the growth rate of the July strains in this study, which was incubated near its optimum temperature. On the other hand, growth rates of the March strains were similar to that of laboratory experiments conducted at the same temperature $\left(18^{\circ} \mathrm{C}\right)$ and salinity (30 psu) (i.e. ca. 0.22 divisions day-1; Yamamoto et al., 2002). However, we can not explain the contrasting growth rates despite being isolated from the same season and area. Further studies are required to investigate if the difference is related to hereditary characteristics or other physiologically related factors.

Average toxin content of the March strains was 2 times higher than that of the July strains. This discrepancy was similar to that of the laboratory experiment. Causative factors may be related to the production of intracellular amino acid, which is a precursor in toxin biosynthesis. In amino acid synthesis nitrate should be reduced to ammonium by the sequential action of nitrate reductase (Lomas and Glibert, 1999). Enzyme activity increases with decreased temperature (Kristiansen, 1983; Gao et al., 1993; 2000). Thus, increasing of toxin content might have been caused by increasing of intercellular amino acid at relatively low temperature. Anderson et al. (1990) also proposed the hypothesis that the effect of low temperature was to reduce protein synthesis, and surplus of arginine within the cell could be used for toxin synthesis. The other reason for increase of toxin content with decreasing temperature may be related to growth rate. High growth rate with optimum temperature conditions and no nutrient limitation may decrease toxin content (Fig. 5). This may be because of transfer of toxic content to daughter cells with faster division (Anderson et al. 1990). These results may be a possible explanation for the G. catenatum related PSP event in Inokushi Bay inn summer.

Our study confirmed that the major toxins in the March and July strains were C1+2 and GTX5+6. In previous studies, major $G$. catenatum toxins isolated from Australia, Japan, Philippine, Portugal and Spain were shown to be C1-4 and GTX 5+6 (Franca et al., 1993; Fukuyo et al., 1993; Ikeda et al., 1989; Ohsima et al., 1993a, b; Takatani et al., 1998), However, Japan strains have been reported to be devoid of $\mathrm{C} 3+4$ (Ohsima et al., 1993a, b). Singapore strains were also clearly distinguished from those of other countries by the complete absence of C3+4 (Holmes et al., 2002).

One-way ANOVA indicated that the $\mathrm{C} 1+2$ and GTX5 +6 proportions of the March strains were significantly different from those of the July strains $(\mathrm{P}<0.001)$, attributed to carbamoyl toxins in the July strains increasing with decreasing $\mathrm{N}$-sulfocarbamoyl toxins in the March strains. Oshima et al. (1993a) and Flynn et al. (1996) reported that toxin profile in G. catenatum is not significantly affected by temperature, light or nutrient status. If toxin profile is stable as reported by Oshima et al. (1993a) and Flynn et al. (1996), the March population might be different to the July population.

However, we observed major changes in toxin profile with increased temperature (Fig. 9). Some authors have reported changes in the composition of PSP affected by physical and chemical environmental parameters (Anderson, 1990; Sakamoto and Kotani, 1998; Hwang and Lu, 2000; Ichimi et al., 2002). Thus, by considering 
the percentage of toxin profile based on temperature variation, the March and July strains could probably be the same population. However, some strains are significantly different from those of other strains. Our study observed GTX1+4 from 7 strains (GCINO2002M17, 27, 29, 56, 57 and 67) among the March strains. This toxin has not been previously reported, except from Singapore strains (Holmes et al., 2002). Furthermore, in NeoSTX+STX, 3 strains (GCINO2002M17, 25 and 56) from the March strains reached more than 10 mol\%. These results suggested that some strains could be distinguished from populations of $G$. catenatum species in Inokushi Bay, raising the probability that these strains were introduced from other regions (Ichimi et al., 2002). Based on toxicological analysis, we showed that $G$. catenatum blooms in March and July may have originated from one and the same population. Future research initiatives needs to investigate the population dynamics of strains based on molecular biological methods, such as gene analysis, in order to validate the results of this study.

\section{ACKNOWLEDGEMENTS}

We are grateful to Prof. Y. Oshima of Tohoku University, as well as the Fisheries Agency of Japan for providing the PSP toxin standards.

\section{REFERENCES}

Anderson, D. M. 1990 Toxin variability in Alexandrium species. In "Toxic Marine Phytoplankton", ed. by E. Granéli, B. Sundtröm, L. Edler and D. M. Anderson, Elsevier, New York, pp. $41-51$

Anderson, D. M., J. J. Sullivan and B. Reguera 1989 Paralytic shellfish poisoning in Northwest Spain: the toxicity of the dinoflagellate Gymnodinium catenatum. Toxicon, 27: 665-674

Baba, T., S. Hiyama and T. Tainaka 2001 Vertical migration of the toxic dinoflagellate Gymnodinium catenatum toxicity of cultured oyster in Senzaki Bay, Yamaguchi Prefecture. Bull. Plankton Soc. Japan, 48: 95-99 (In Japanese with English abstract)

Blackburn, S. I., G. M. Hallegraeff and C. J. Bolch 1989 Vegetative reproduction and sexual life cycle of the toxic dinoflagellate Gymnodinium catenatum from Tasmania, Australia. $J$. Phycol., 25: 577-590

Boczar, B. A., M. K. Beitler, J. Liston, J. J. Sullivan, and R. A. Cattolico 1988 Paralytic shellfish toxins in Protogonyaulax tamarensis and Protogonyaulax catenella in axenic culture. Plant. Physiol., 88: 1285-1290

Boyer, G. L., J. J. Sullivan, R. J. Anderson, P. J. Harrison and F. J. R. Taylor 1987 Effects of nutrient limitation on toxin production and composition in the marine dinoflagellate Protogonyaulax tamarensis. Mar. Biol., 96: 123-128

Bravo, I. and D. M. Anderson 1994 The effects of temperature, growth medium and darkness on excystment and growth of the toxic dinoflagellate Gymnodinium catenatum from northwest Spain. J. Plankton Res., 16: 513-525

Cembella, A. E., J. J. Sullivan, G. L. Boyer, F. J. R. Taylor and R. J. Anderson 1987 Variation in paralytic shellfish toxin composition within the Protogonyaulax tamarensis/catenella species complex: red tide dinoflagellates. Biochem. Syst. Ecol., 15: $171-186$

Chang, F. H., D. M. Anderson, D. M. Kulis and D. Till 1997 Toxin production of Alexandrium minutum (Dinophyceae) from the Bay of Plenty, New Zealand. Toxicon, 35: 393-409
Ellegaard, M., N. F. Christensen and Ø. Moestrup 1993 Temperature and salinity effects on growth of a non-chainforming strain of Gymnodinium catenatum (Dinophyceae) established from a cyst from recent sediments in the sound (Øresund), Denmark. J. Phycol., 29: 418-426

Estrada, M., F. J. Sanchez and S. Fraga 1984 Gymnodinium catenatum (Graham) en las rías gallegas (NO de Espana). Invest. Pesq., 48: 31-40

Franca, S., P. Alvito, I. Sousa and V. Mascarenhas 1993 The dinoflagellate Gymnodinium catenatum isolated from the coast of Portugal: Observations on development, toxicity and ultrastructure. In "Toxic Phytoplankton Blooms in the Sea", ed. by T. J Smayada and Y. Shimizu, Elsevier, Amsterdam, pp. 869-874

Flynn, K. J., K. Flynn, E. H. John, B. Reguera, M. I. Reyero and J. M. Franco 1996 Changes in toxins, intracellular and dissolved free amino acids of the toxic dinoflagellate Gymnodinium catenatum in response to changes in inorganic nutrients and salinity. J. Plankton Res., 18: 2093-2111

Fukuyo, Y., M. Kodama and T. Ogata 1993 Occurrence of Gymnodinium catenatum in Manila Bay, the Philippines. In "Toxic Phytoplankton Blooms in the Sea", ed. by T. J. Smayda and Y. Shimizu, Elsevier, Amsterdam, pp. 875-880

Gao, Y., G. J. Smith and R. S. Alberte 1993 Nitrate Reductase from the Marine Diatom Skeletonema costatum. Plant Physiol. 103: $1437-1445$

Gao, Y., G. J. Smith and R. S. Alberte 2000 Temperature dependence of nitrate reductase activity in marine phytoplankton: biochemical analysis and ecological implications. J. Phycol., 36: 304-313

Guillard, R. R. L. and D. Ryther 1962 Studies of marine planktonic diatoms. I. Cyclotella nana Hustedt and Detonula confervacea (Cleve) Gran. Can. J. Microbiol., 8: 229-239

Hada, Y. 1967 Protozoan plankton of the Inland Sea, Setonaikai I. The mastigophora. Bull. Suzugamine Woman's Coll., Nat. Sci., 13: 1-26

Hallegraeff, G. M. and C. J. Bolch 1992 Transport of diatom and dinoflagellate resting spores in ships' ballast water: implications for plankton biogeography and aquaculture. J. Plankton Res., 14: 1067-1084

Hallegraeff, G. M. and S. Fraga 1998 Bloom dynamics of the toxic dinoflagellate Gymnodinium catenatum, with emphasis on Tasmanian and Spanish coastal waters. In "Physiological Ecology of Harmful Algal Blooms", ed. by D. M. Anderson, A. D. Cembella and G. M. Hallegraeff, Springer, Berlin, pp. 59-80

Hallegraeff, G. M., S. O. Stanley, C. J. Bolch and S. I. Blackburn 1989 Gymnodinium catenatum blooms and shellfish toxicity in southern Tasmania, Australia. In "Red Tides: Biology, Environmental Science and Toxicology", ed. by T. Okaichi, D. M. Anderson and T. Nemoto, Elsevier, New York, pp. 77-80

Hang, D. F. and Y. H. Lu 2000 Influence of environmental and nutritional factors of growth, toxicity, and toxin profile of dinoflagellate Alexandrium minutum. Toxicon, 38: 1491-1503

Holmes, M. J., C. J. Bolch, D. H. Green, A. D. Cembella, S. Lay and M. Teo 2002 Singapore isolates of the dinoflagellate Gymnodinium catenatum (Dinophyceae) produce a unique profile of paralytic shellfish poisoning toxins. J. Phycol., $\mathbf{3 8}$ 96-106

Ichimi, K., T. Suzuki and A. Ito 2002 Variety of PSP toxin profiles in various culture strains of Alexandrium tamarense and change of toxin profile in natural A. tamarense population. $J$. Exp. Mar. Biol. Ecol., 273: 51-60

Ishida, Y., C. H. Kim, Y. Sako, N. Hirooka and A. Uchida 1993 PSP toxin production is chromosome dependent in Alexandrium spp. In "Toxic Phytoplankton Blooms in the Sea", ed. by T. J. Smayda and U. Shimizu, Elsevier, Amsterdam, pp. 881-887

Ikeda, T., S. Matsuno, S. Sato, T. Ogata, M. Kodama, Y. Fukuy and H. Takayama 1989 First report on paralytic shellfish poisoning caused by Gymnodinium catenatum (Dinophyceae) in Japan. In "Red Tides", ed. by T. Okaichi, D. M. Anderson and T. Nemoto, Elsevier, New York, pp. 411-414

Kristiansen, S. 1983 The temperature optimum of the nitrate 
reductase assay for marine phytoplankton. Limnol. Oceanogr., 28: 776-780

Lomas, M. W. and P. M. Glibert 1999 Temperature regulation of nitrate uptake: A novel hypothesis about nitrate uptake and reduction in cool-water diatom. Limnol. Oceanogr., 44: 556572

Maranda, L., D. M. Anderson and Y. Shimizu, 1985 Comparison of toxicity between populations of Gonyaulax tamarensis of eastern North American waters. East. Coast. Shelf. Sci., 21: 401-410

Matsuoka, K. and Y. Fukuyo 1994 Geographical distribution of the toxic dinoflagellate Gymnodinium catenatum Graham in Japanese coastal waters. Botanica Marina, 37: 495-503

Miyamura, K., Y. Matsuyam and S. J. Oh 2007 Occurrence of the toxic dinoflagellate Gymnodinium catenatum, toxin contents of suspended matter and prediction of PSP outbreak in the scallop Chlamys nobilis in Inokushi Bay, Oita Prefecture. Nippon Suisan Gakkaishi, 73: 32-42 (in Japanese with English abstract)

Morey-Gaines, G. 1982 Gymnodinium catenatum (Dinophyceae): morphology and affinities with armored forms. Phycologia, 21: 154-163

Nishioka J., Y. Wada and Y. Imanishi 1993 On the occurrence of Gymnodinium catenatum (Dinophyceae) in Kumihama Bay. Bull. Kyoto Inst. Ocean. Fish. Sci., 16: 43-49 (in Japanese with English abstract)

Ogata T., T. Ishimaru and M. Kodama 1987 Effect of water temperature and light intensity on growth rate and toxicity change in Protogonyaulax tamarensis. Mar. Biol., 95: 217-220

Oh, S. J. and Y. H. Yoon 2004 Effects of water temperature, salinity and irradiance on the growth of the toxic dinoflagellate, Gymnodinium catenatum (Graham) isolated from Yeosuhae Bay, Korea. Algae, 19: 293-302 (in Korean with English abstract)

Oshima, Y. 1995 Post-column derivatization HPLC methods for paralytic shellfish poisons. In "Manual on Harmful Marine
Microalgae", ed. by G. M. Hallegraeff, D.M. Anderson and A. D. Cembella, UNESCO, Paris, pp. 81-94

Oshima, Y., S. I. Blackburn and G. M. Hallegraeff 1993a Comparative study on paralytic shellfish toxin profiles of the dinoflagellate Gymnodinium catenatum from three different countries. Mar. Biol., 116: 471-476

Oshima, Y., H. Itakura, K. Lee, T. Yasumoto, S. Blackburn and G. Hallegraeff 1993b Toxin production by the dinoflagellate Gymnodinium catenatum. In "Toxic phytoplankton blooms in the sea", ed. by T. J. Smayda and Y. Shimizu, Elsevier, New York, pp. 907-912

Oshima, Y., M. Hasegawa, T. Yasumoto, G. Hallegraeff and S. Blackburn 1987 Dinoflagellate Gymnodinium catenatum as the source of paralytic shellfish toxins in Tasmanian shellfish. Toxicon, 25: 1105-111

Park, T. G., C. H. Kim and Y. Oshima 2004 Paralytic shellfish toxin profiles of different geographic populations of Gymnodinium catenatum (Dinophyceae) in Korean coastal waters. Phycol. Res., 52: 300-305

Sakamoto, S. and Y. Kotani 1998 Variation of paralytic shellfish contents and composition in Alexandrium tamarense collected at Kure Bay, Hiroshima prefecture. Bull. Nansei. Natl. Fish. Res. Inst., 31: 45-52 (in Japanese with English abstract)

Takatani, T., T. Morita, A. Anami, H. Akaeda, Y. Kamijo, K Tsutsumi, T. Noguchi 1998 Appearance of Gymnodinium catenatum in association with the toxification of bivalves in Kamae, Oita Prefecture, Japan. J. Food Hyg. Soc. Japan., 39 275-280

Taroncher-Oldenburg, G., D. M. Kulis and D. M. Anderson 1997 Toxin variability during the cell cycle of the dinoflagellate Alexandrium fundyense. Limnol. Oceanogr., 42: 11781188

Yamamoto, T., S. J. Oh and Y. Kataoka 2002 Effect of temperature, salinity and irradiance on the growth of the toxic dinoflagellate Gymnodinium catenatum (Dinophyceae) isolated from Hiroshima Bay, Japan. Fisheries Sci., 68: 356-363 